\title{
WestVirginiaUniversity
}

THE RESEARCH REPOSITORY @ WVU

Graduate Theses, Dissertations, and Problem Reports

2018

\section{Delay Discounting and Cannabinoid Enzyme Inhibitors}

Devin Andrew Galdieri

dag0018@mix.wvu.edu

Follow this and additional works at: https://researchrepository.wvu.edu/etd

Part of the Experimental Analysis of Behavior Commons, Pharmacology Commons, and the Quantitative Psychology Commons

\section{Recommended Citation}

Galdieri, Devin Andrew, "Delay Discounting and Cannabinoid Enzyme Inhibitors" (2018). Graduate Theses, Dissertations, and Problem Reports. 3684.

https://researchrepository.wvu.edu/etd/3684

This Thesis is protected by copyright and/or related rights. It has been brought to you by the The Research Repository @ WVU with permission from the rights-holder(s). You are free to use this Thesis in any way that is permitted by the copyright and related rights legislation that applies to your use. For other uses you must obtain permission from the rights-holder(s) directly, unless additional rights are indicated by a Creative Commons license in the record and/ or on the work itself. This Thesis has been accepted for inclusion in WVU Graduate Theses, Dissertations, and Problem Reports collection by an authorized administrator of The Research Repository @ WVU. For more information, please contact researchrepository@mail.wvu.edu. 
Delay Discounting and Cannabinoid Enzyme Inhibitors

Devin Andrew Galdieri

\author{
Thesis submitted \\ to the Eberly College \\ at West Virginia University \\ in partial fulfillment of the requirements for the degree of \\ Master of Science in \\ Psychology
}

\author{
Karen G. Anderson, Ph.D., Chair \\ Regina A. Carroll, Ph.D. \\ Steven G. Kinsey, Ph.D. \\ Department of Psychology
}

\author{
Morgantown, West Virginia \\ 2018
}

Keywords: Cannabinoid enzyme inhibitors, impulsive choice, impulsivity, delay discounting Copyright 2018 Devin Galdieri 


\begin{abstract}
Delay Discounting and Cannabinoid Enzyme Inhibitors
\end{abstract}

Devin Andrew Galdieri

Delay discounting is a measure of impulsive choice that is correlated with maladaptive behavior and psychological disorders. Disruptions to serotonin and dopamine pathways can cause changes in delay discounting, as can lesions to the prefrontal cortex and nucleus accumbens. The endocannabinoid system modulates other neurotransmitter systems, including dopamine and serotonin pathways. Cannabinoid receptors type 1 are found in relatively high concentrations in the nucleus accumbens and the prefrontal cortex. These receptors are activated by endogenous cannabinoids, which are synthesized on demand and broken down by catabolic enzymes. The action of these enzymes can be inhibited by a class of drugs known as cannabinoid enzyme inhibitors, which ultimately produce higher levels of endogenous cannabinoids by preventing their catabolic degradation. The present study examined effects of two cannabinoid enzyme inhibitors, URB597 and JZL195, on delay discounting in rats. Delay discounting was measured at baseline and after drug administration. Area under the curve and indifference points were not affected by any dose of either drug, but $7.5 \mathrm{mg} / \mathrm{kg}$ of JZL195 decreased percent larger-reinforcer choice at the lowest delay value and increased it at the highest delay value. URB597 increase percent larger-reinforcer choice only at one intermediate delay value. JZL195 increased response latencies at the $7.5 \mathrm{mg} / \mathrm{kg}$ dose. No systematic, dose-dependent effect of either drug on measures of delay discounting was observed. 


\section{ACKNOWLEDGEMENTS}

I would like to thank Dr. Karen Anderson, Dr. Regina Carroll, and Dr. Steven Kinsey for their time, guidance and feedback as members of my thesis committee. I am sincerely grateful for all of the mentorship, training, and support that Dr. Karen Anderson, my advisor, has provided throughout my graduate career. I would like to express my gratitude to Dr. Steven Kinsey for his expert advice and guidance on the subject of cannabinoids and the endocannabinoid system. I would like to acknowledge the training that I have received from all of the excellent faculty at West Virginia University and I would also like to thank my colleagues Jenny Ozga-Hess and Matt Eckard for training me in the lab, helping me with experiments and lab work, and generally being wonderful lab-mates. Thank you, as well, to my mother and father, Janis Cross and Michael Galdieri, for their unconditional love and support. Last but not least, thank you to all of my friends in West Virginia, California, and everywhere else, for keeping me sane and motivated: Natalie Jones, Kristine Durkin, Ashlee Gresham, Jacob Solomon, Hannah JonesOzanian, Jesse Ozanian, Charles Curtis, and Edward Weaver. 


\section{TABLE OF CONTENTS}

\section{Page}

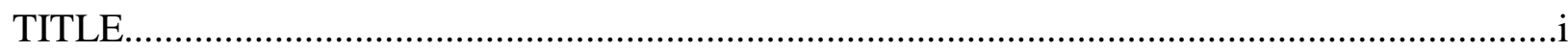

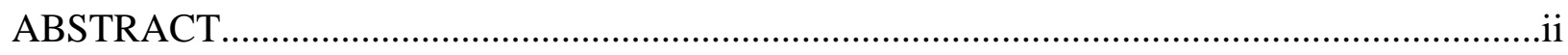

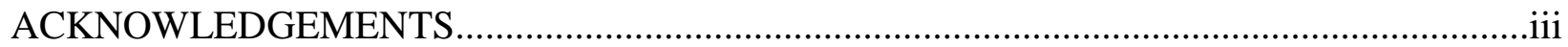

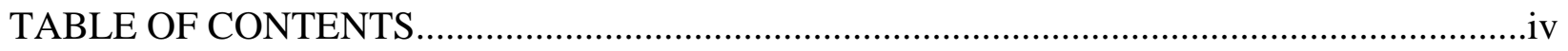

LIST OF FIGURES...........................................................................................................

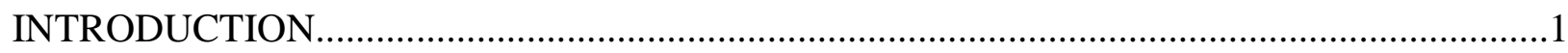

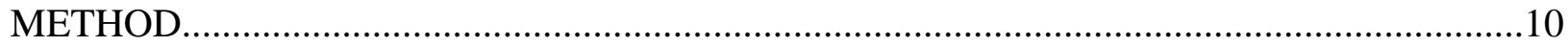

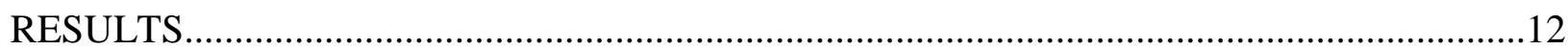

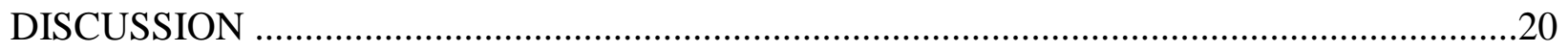

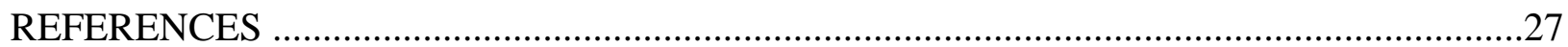

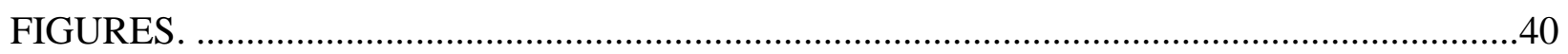

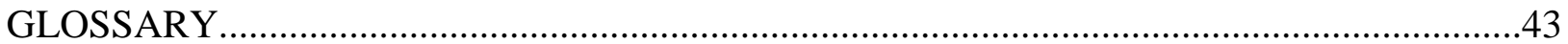




\section{LIST OF FIGURES}

Figure 1

Mean percentages of larger-reinforcer choice as a function of delay value for all rats when vehicle, URB597 or JZL195 were administered.

Figure 2.

Mean percentages of larger-reinforcer choice as a function of delay value for individual rats when vehicle or URB597 was administered.

Figure 3.

Mean percentages of larger-reinforcer choice as a function of delay value for individual rats when vehicle or JZL195 was administered. 
Delay Discounting and Cannabinoid Enzyme Inhibitors

Delay discounting, a measure of impulsivity, has been implicated in a number of disorders and maladaptive behaviors including pathological gambling, substance abuse, attention-deficit/hyperactivity disorder (ADHD), schizophrenia, personality disorders, suicidality, and psychopathology in general (Castellanos-Ryan et al., 2016; Dom, De Wilde, Hulstijn, Brink, \& Sabbe, 2006; Heerey, Robinson, McMahon, \& Gold 2007; Kirby, Petry, \& Bickel, 1999; Rogers, Moeller, Swann, \& Clark, 2010; Wiehler \& Peters, 2015; Wilson, Mitchell, Musser, Schmitt, \& Nigg, 2011). One facet of impulsivity is impulsive choice, which can be defined as the choice of a smaller, more immediate reinforcer over a larger, delayed reinforcer (Ainslie, 1974, 1975). Conversely, self-control has been defined as the choice of a larger delayed reinforcer over a relatively smaller immediate reinforcer (Rachlin \& Green, 1972).

The purpose of the present experiment was to assess effects of drugs that alter the endocannabinoid system using a procedure designed to measure impulsive choice. Delaydiscounting procedures are commonly used to assess impulsive choice and there is experimental evidence that implicates serotonin (5-HT) and dopamine (DA), as well as the prefrontal cortex (PFC) and nucleus accumbens (NAc) in increased delay discounting (impulsive choice) (e.g., Bizot, Le Bihan, Puech, Hamon, \& Thiébot, 1999; Cardinal, 2006; Evenden \& Ryan, 1996; Winstanley, Theobald, Cardinal, \& Robbins, 2004). The endocannabinoid system is an attractive target for research in general due to its therapeutic potential, and in terms of delay-discounting research, due to its effects on the neurotransmitter systems for 5-HT and DA and brain regions in the PFC and NAc (e.g., Lòpez-Moreno, González-Cuevas, Moreno, \& Navarro, 2008; Reggio 2009). There are two main receptor types in the endocannabinoid system and two main endogenous compounds that activate them (Reggio, 2009). The different physiological and 
behavioral effects that follow activation of these different receptors and the neurotransmitters and brain regions affected by them provided rationale for choosing the drugs used in this study and those drugs' likelihood of producing effects on delay discounting. Prior operant research on the endocannabinoid system is sparse and results are mixed, but the established therapeutic potential and long list of unanswered research questions suggest that there is still much to learn, particularly in matters of impulsivity and choice.

\section{Delay-Discounting Procedures}

Impulsive choice can be assessed several different ways. Delay discounting refers to a decrease in perceived value of a reinforcer as a function of the delay to that reinforcer. In this case, the impulsive choice would be selecting the smaller, more immediate reinforcer over the larger, delayed reinforcer. While impulsivity has been studied using different constructs and procedures (e.g., probability discounting, response inhibition), delay discounting is represented in a broad and robust body of behavior-analytic and pharmacological research.

Impulsive choice has been measured with delay-discounting procedures across species for several decades (Vanderveldt, Oliveira, \& Green, 2016), with many studies investigating pharmacological manipulations (e.g., Cardinal, Robins, \& Everitt, 2000; Evenden \& Ryan, 1999; Winstanley et al., 2004) and brain lesions (e.g., Cardinal, Pennicott, Sugathapala, Robbins, \& Everritt, 2001; Mobini, Chiang, Ho, Bradshaw, \& Szabadi, 2000; Mobini et al., 2002). A common delay-discounting procedure involves two choices presented simultaneously in discrete trials: one choice is associated with a larger, delayed reinforcer and one is associated with a smaller, more immediate reinforcer (e.g., Anderson \& Woolverton, 2005; Evenden \& Ryan, 1999). The value of the larger reinforcer is said to be discounted as a function of delay, which is reflected in a shift in choice from the larger to the smaller reinforcer (i.e., from self-controlled 
choice to impulsive choice) as the delay value increases. Responding in a delay-discounting procedure can typically be fitted to a hyperbolic curve, and several parameters of this curve can serve as quantitative measures of delay discounting (Mitchell, Wilson, \& Karalunas, 2015). The area under the curve (AUC) of the delay-discounting function and the interpolated delay values at which the percent choice for the smaller and larger reinforcer are equal (indifference points) are two such measures (Myerson, Green, \& Warusawitharana, 2001; Odum, 2011). Individuals who display many of the maladaptive behaviors mentioned above often have steeper delaydiscounting functions, lower AUC, and shorter indifference points, i.e., more impulsive choice, than the general population (e.g., Alessi \& Petry, 2003; Amlung, Vedelago, Acker, \& Balodis, Mackillop, 2016; Bickel, Odum, \& Madden, 1999; Moody, Franck, \& Bickel, 2016). Delaydiscounting procedures (described further in the Method section) have been effective at detecting effects of numerous drugs, including methylphenidate, amphetamine, nicotine, caffeine, and diazepam (Anderson \& Diller, 2010; Diller, Saunders, \& Anderson, 2008; Huskinson \& Anderson, 2012; Krebs, Reilly, \& Anderson, 2016; Slezak, \& Anderson, 2011). Based on the ability of this procedure to detect impulsivity-altering effects of numerous drugs, and the relation between delay discounting and maladaptive behaviors related to impulse control, delaydiscounting procedure may serve as a useful tool to expand understanding of how the endocannabinoid system affects socially important behavior.

\section{Delay Discounting and Monoamines}

Agonists (compounds that increase the physiological action associated with a given receptor) that act on a variety of neurotransmitter systems have been studied for their effects on delay discounting. In particular, 5-HT and DA have been identified as major contributors to delay discounting, and many of the drugs that affect delay discounting directly affect 5-HT and 
DA pathways (see Cardinal, 2006 for a review). Researchers investigating effects of stimulants such as $d$-amphetamine and methylphenidate (e.g., Cardinal, Robbins, \& Everitt, 2000; Perry, Stairs, \& Bardo, 2008) and 5-HT agonists such as fluoxetine and ketanserin (Carlisi et al., 2016; Darna et al., 2015) have demonstrated that, in some cases, drugs that increase DA and 5-HT activity can alter delay discounting. Although effects are often baseline-dependent, DA and 5-HT agonists tend to decrease delay discounting. Furthermore, lesions to 5-HT and DA systems in various brain regions, including the NAc and PFC, can affect delay discounting; however, the type of delay-discounting task, method of lesion, and the exact location of the lesion determined the directionality of effects on delay discounting (e.g., Basar et al., 2010; Bizot et al., 1999; Mobini, et al., 2000; Moschak \& Mitchell, 2014; Simmons, Minamimoto, Murray, \& Richmond, 2010). Although many neurotransmitters and brain regions are likely involved in delay discounting, an abundance of evidence suggests 5-HT and DA are strong contributors and that the NAc and PFC are involved as well.

Interestingly, the endocannabinoid system nodulates activity of both DA and 5-HT in the NAc and PFC and an abundance of cannabinoid receptors are present in these brain regions (Herkenham et al., 1990; Lòpez-Moreno et al., 2008). Given the endocannabinoid system’s involvement in neurotransmitter systems already known to affect delay discounting and its high receptor density in brain regions associated with delay discounting, it is not surprising that drugs that affect the endocannabinoid system can affect delay discounting (see Moreira, Jupp, Belin, \& Dalley, 2015 for a review). Still, relatively little is known about the endocannabinoid system and its role in delay discounting. 


\section{The Endocannabinoid System}

The endocannabinoid system modulates activity of other neurotransmitters following activation of its own receptors (Reggio, 2009). The cannabinoid receptors include cannabinoid receptor type 1 (CB1) and cannabinoid receptor type 2 (CB2), although several other receptor types without known endogenous ligands have been implicated as potential cannabinoid receptor types based on the affinity of various endogenous and exogenous cannabinoids for those receptors (Brown, 2007; Reggio, 2009). While CB1 receptors are found primarily on neuronal cells and in the brain, CB2 receptors are found predominantly on immune cells and peripheral tissue (Pertwee, 2004). There are three types of compounds that act directly on these receptors. Phytocannabinoids are the cannabinoids found in the plant Cannabis sativa and thus used in the recreational drug marijuana. Synthetic cannabinoids are man-made cannabinoids that often mimic naturally occurring cannabinoids and are developed and used in research settings. Although now widely illegal, synthetic cannabinoid agonists have been marketed for recreational use under such vague descriptions as "synthetic marijuana," "herbal blends," or "Spice” (Kemp et al., 2016). Endogenous cannabinoids (endocannabinoids) are those that are produced naturally in the bodies of animals (Lòpez-Moreno et al., 2008; Reggio, 2009). In addition to these natural and synthetic cannabinoid agonists, there are also compounds that indirectly increase activity at the cannabinoid receptors, such as cannabinoid enzyme inhibitors. Cannabinoid enzyme inhibitors reduce the ability of the enzymes that are responsible for catabolic degradation of the two known endocannabinoids (although other endocannabinoids may exist): arachidonoylglycerol (2-AG) and anandamide (AEA). Monoacylglycerol lipase (MAGL) is the enzyme that is responsible for the majority of 2-AG metabolism; fatty acid amide hydrolase (FAAH) is the enzyme that is responsible for the majority of AEA metabolism, as well as a small 
amount of metabolism of 2-AG and some other non-cannabinoid compounds (Ahn, McKinney, \& Cravatt, 2008). Pharmacological inhibition of these enzymes results in increased levels of endogenous cannabinoids, and thus, increased activity at the cannabinoid receptors (Ahn, et al., 2008).

Because CB1 is the cannabinoid receptor found primarily on neuronal cells, and because of the high density of CB1 receptors in areas such as the NAc and PFC, it is not surprising that a majority of behavioral research on cannabinoids and impulsivity implicate CB1 (Moreira et al., 2015). CB1 receptors are activated by both AEA and 2-AG, although there are differences in affinity and efficacy between the two endocannabinoids at both cannabinoid receptors. Because FAAH is the primary compound responsible for degradation of AEA, inhibition of FAAH increases levels of AEA (as well as other fatty acid amides). Drugs that inhibit FAAH, and thus slow the degradation of AEA, often exert similar effects as CB1 agonists as a result of increased AEA activity (Moreira et al., 2015). MAGL inhibitors can also produce effects similar to CB1 agonists by increasing 2-AG levels, and thus increasing CB1 activity (Reggio, 2009). Enzyme inhibitors are an indirect method of increasing CB1 activity because they operate strictly by altering levels of endogenous cannabinoids, and may produce fewer side effects than direct agonists (e.g., Alvarez-Jaimes \& Palmer, 2011; Piomelli et al., 2006). Thus, the present study will focus on effects of increased AEA and 2-AG levels through drugs that inhibit FAAH or a combination of FAAH and MAGL.

\section{Delay Discounting and Cannabinoids}

Delta-9 tetrahydrocannabinol (THC) and synthetic cannabinoid agonists are widely consumed worldwide and are legal in many states (“Marijuana,” 2017). Given the proliferation of cannabinoid use, the endocannabinoid system's involvement in both DA and 5-HT systems 
(Lòpez-Moreno et al., 2008), and the high concentration of CB1 receptors in the NAc and PFC (Dove Pettit, Harrison, Olson, Spencer, \& Cabral, 1998; Herkenham et al., 1990), investigation into the safety and efficacy of drugs that affect this system is warranted. There is limited research with inconsistent findings on the relation between the endocannabinoid system and delay discounting (e.g., Tanno, Maguire, Henson, \& France, 2014; Wiskerke, Stoop, Schetters, Schoffelmeer, \& Pattij, 2011), and although enzyme inhibitors may be the least addictive and least harmful of cannabinoid drugs (e.g., Alvarez-Jaimes \& Palmer, 2011; Piomelli et al., 2006), they have received minimal attention in operant research. The lack of consistent evidence regarding delay discounting and the endocannabinoid system may be due in part to several reasons, including methodological differences across experiments, the variety of natural and synthetic agonists that act on cannabinoid receptor sites, and/or the inherent complexity of a neurotransmitter system that modulates other neurotransmitter systems.

Delta-9 tetrahydrocannabinol. THC, naturally found in Cannabis sativa, is a partial agonist for both CB1 and CB2 (Govaerts, Hermans, \& Lambert, 2004). Effects of THC on delay discounting have been studied in both humans and non-human animals, with conflicting results and varying degrees of methodological consistency (e.g., McDonald, Schleifer, Richards, \& de Wit, 2003; Metrik et al., 2013). In human research, the delay-discounting data have come primarily from hypothetical questions such as "Would you rather have $\$ 10.00$ in 30 days or $\$ 2.00$ at the end of the session?” administered after participants either inhaled marijuana smoke or ingested capsules containing varying amounts of THC (McDonald et al., 2003; Metrik et al., 2013). Neither McDonald et al. (2003) nor Metrik et al. (2013) found significant differences between drug and placebo groups in delay discounting. However, due in part to the difficulty in obtaining accurate doses via smoke inhalation, the potential validity issues inherent in self- 
reported dependent measures (e.g., Lloyd, 1992), and the differences between pure THC and the mixture of 80 or more cannabinoids found in marijuana (El-Alfy et al., 2010), further investigation into THC’s effects on delay discounting in humans is needed.

In non-human animal research, procedures and results have varied considerably as well. In a recent study, Tanno, et al., (2014) exposed experimentally naïve Sprague-Dawley rats to a delay-discounting procedure in which rats were given a choice between two levers: one associated with three pellets after a signaled delay $(0,4,8,16$, or $32 \mathrm{~s})$, and one associated with a single pellet delivered immediately. After an initial experiment in which rats were exposed to amphetamine, methylphenidate, and morphine and tested on a delay-discounting procedure, doses of 0.32 , 3.2, and $5.6 \mathrm{mg} / \mathrm{kg}$ of THC were administered. A dose-dependent increase in delay discounting (more impulsive choice) was observed after THC administration. Wiskerke et al., (2011) trained Wistar rats to respond by nose-poking into one of two holes: one associated with four food pellets and an unsignaled delay $(0,5,10,20$, or 40 s), and another associated with one food pellet presented immediately. After exposure and testing with combinations of amphetamine, and several synthetic cannabinoid agonists, rats were given doses of THC alone at 0.5, 1.0, and $2.0 \mathrm{mg} / \mathrm{kg}$. A dose-dependent decrease in delay discounting (less impulsive choice) was observed, and a statistically significant decrease from vehicle was found at the $2.0 \mathrm{mg} / \mathrm{kg}$ dose. These opposing findings, although likely in part a reflection of methodological differences, suggest a complex role for the endocannabinoid system in delay discounting.

Synthetic cannabinoids. The cannabinoid system can also be manipulated with synthetic cannabinoids, many of which are agonists that act directly on CB1 receptors. In a procedure similar to that of Wiskerke and colleagues, (2011), Pattij and colleagues (2007) found no changes in delay discounting for Wistar rats following acute administration of the potent CB1 
synthetic agonist WIN55,212-2 in doses up to $3.0 \mathrm{mg} / \mathrm{kg}$. Adriani, Caprioli, Granstrem, Carli, and Levola (2003) used a procedure with signaled delays (0, 10, 20, 30, 45, 60, 80, $100 \mathrm{~s})$ and five food pellets delivered for nose-pokes associated with the larger reinforcer. Under this procedure, they observed decreases in delay discounting (less impulsive choice) after acute administration of WIN55,212-2 (2.0 mg/kg) in Spontaneously Hypertensive Rats with reduced CB1 receptor density, but not in Wistar-Kyoto rats with normal CB1 receptor density. Similar to non-human animal research with THC, this limited and inconsistent experimental evidence with synthetic agonists suggests that further research is needed to understand the complex role that the endocannabinoid system plays in delay discounting.

Enzyme inhibitors. Few studies have been conducted that directly examine the effects of cannabinoid enzyme inhibitors on delay discounting, but what evidence there is suggests a relation may exist. Marco et al. (2007) found that a low dose of the potent FAAH inhibitor URB597 resulted in decreases in delay discounting for Wistar rats that had experienced early maternal deprivation, but not for control rats. Just as in the above-mentioned studies, results from Marco et al., (2007) suggest a complex relation between the endocannabinoid system and delay discounting.

FAAH inhibitors, like URB597, also have therapeutic promise in a number of areas outside of delay discounting. In non-human animals, URB597 can reverse cannabinoid- and morphine-induced cognitive deficits, prevent tolerance to morphine, promote social behavior, reduce nausea and inflammation, prevent and reverse symptoms of depression and anxiety, and promote analgesia, all with minimal abuse potential (Bortolato et al., 2007; Cross-Mellor, Ossenkopp, Piomelli, \& Parker, 2007; Hasanein \& Ghafar-Vahed, 2016; Hasanein \& Teimuri Far, 2015; Jayamanne et al., 2006; Justinova et al., 2008; Kwilasz, Abdullah, Poklis, Lichtman, 
\& Negas, 2014; Manduca et al., 2014; Stunkard, 2009). Given its potential for therapeutic use in these other areas and its aforementioned minimal health risks and low potential for abuse, URB597 should be studied further for its potential behavioral effects on impulsive choice in a delay-discounting procedure.

Although FAAH inhibitors have been studied for their effects on delay discounting to some extent, no studies to date have been published on the role of MAGL inhibitors in delay discounting. Selective MAGL inhibitors are mostly studied for their physiological effects, but the dual FAAH/MAGL inhibitor JZL195 exerts strong motoric effects in rats (Seillier, Dominguez Aguilar, \& Giuffrida, 2014). Effects of dual FAAH/MAGL inhibitors such as JZL195 often resemble those of THC on physiological and behavioral responses such as reduced inflammation-induced allodynia, hypolocomotion, and reductions in intracranial self-stimulation and heroin self-administration. Therefore, dual inhibitors could have effects similar to THC on delay discounting (Adamson, Mitchell, Kazantzis, \& Vaughan, 2016; Guindon, 2016; Negus \& Miller, 2014; Pacher, Bàtkai, \& Kunos, 2006; Seillier et al., 2014; Wilkerson et al., 2016).

\section{Statement of the Problem}

Prior research indicates an important but complex role for the endocannabinoid system in delay discounting, as evidenced by changes in measures of delay discounting following administration of cannabinoid drugs, changes in 5-HT and DA levels after administration of such drugs (e.g., Lòpez-Moreno et al., 2008; Marco et al., 2007), and high cannabinoid receptor densities in brain regions involved in delay discounting (Herkenham et al., 1990). The purpose of the present experiment is to assess and compare effects of a FAAH inhibitor and a dual FAAH/MAGL inhibitor on delay discounting in rats. As a FAAH inhibitor, URB597 slows the breakdown of AEA and thus increases the duration of its activity. As a dual FAAH/MAGL 
inhibitor, JZL195 slows the breakdown of 2-AG and AEA and thus increases their durations of activity. Given that URB597 and JZL195 exert many of the same behavioral effects as direct cannabinoid agonists, and that both of these drugs alter levels of endocannabinoids that induce changes in 5-HT and DA in brain regions related to delay discounting, it is likely that they will also have an effect on delay discounting.

\section{Method}

\section{Subjects}

Eight experimentally naïve male Sprague-Dawley rats served as subjects. All rats were pair-housed in controlled environmental conditions (temperature, $24^{\circ} \mathrm{C}$; 12 -h reverse light/dark cycle), with continuous access to water in home cages. Sessions were conducted at approximately the same time each day, five to six days per week (Monday-Saturday). Rats were fed approximately 16 g of food per cage approximately 30 min following sessions, resulting in approximately $22 \mathrm{~h}$ of food restriction. All procedures were approved by the Institutional Animal Care and Use Committee at West Virginia University.

\section{Apparatus}

Sessions were conducted in eight standard operant-conditioning chambers for rats, each enclosed in a melamine sound-attenuating cubicle (Med Associates, VT). Each chamber contained a working area of $30.5 \mathrm{~cm}$ by $24.5 \mathrm{~cm}$ by $21.0 \mathrm{~cm}$, a grid floor, and a $45-\mathrm{mg}$ pellet dispenser with a pellet receptacle centered between two retractable response levers. Levers were $11.5 \mathrm{~cm}$ apart from each other and required at least $0.25 \mathrm{~N}$ of force for a response to be recorded. Levers were $4.8 \mathrm{~cm}$ wide, protruded $1.9 \mathrm{~cm}$ into the chamber, and were elevated $8 \mathrm{~cm}$ from the grid floor. Two 28-V stimulus lights, $2.5 \mathrm{~cm}$ in diameter, were approximately $7 \mathrm{~cm}$ above each lever. Each chamber had a 28-V houselight on the wall opposite to the working wall, and a 
ventilation fan to circulate air and to mask extraneous noise. Data collection and programmed consequences were controlled by a personal computer equipped with Med-PC software (Med Associates, VT).

\section{Drugs}

Vehicle was a 1:2:17 mixture of Tween 80, dimethyl sulfoxide (DMSO), and saline. This ratio was selected to include the smallest amount of DMSO necessary to dissolve the maximum amount of drug used in the study at an injection volume of $2 \mathrm{ml} / \mathrm{kg}$ (Cayman Chemical, 2017; Sigma-Aldrich, 2017). URB597 (3'-(aminocarbonyl)[1,1'-biphenyl]-3-yl)-cyclohexylcarbamate and JZL195 4-nitrophenyl 4-(3-phenoxybenzyl)piperazine-1-carboxylate were purchased from Cayman Chemical. The injection volume of $2 \mathrm{ml} / \mathrm{kg}$ was selected to maximize solubility while reducing potential irritation at the injection site caused by DMSO and because it had been safely used in numerous prior studies involving cannabinoid enzyme inhibitors. Prior studies informed the dose ranges selected for URB597 (Marco et al., 2007) and JZL195 (Seillier et al., 2014). All drugs were prepared from crystalline powder by adding the powder to pre-measured DMSO and crushing it with a metal spatula. The DMSO solution was then warmed to room temperature and sonicated for approximately five minutes. Once no more crystals were visible in the DMSO solution, Tween 80 was added, the solution was sonicated for another approximately 5 min, and saline was added to reach the final solution volume. Drug solutions were prepared no more than one week in advance and stored in a standard refrigerator. Raw crystalline powder was stored in a freezer at $-80{ }^{\circ} \mathrm{C}$. Drugs were injected 50 min prior to the beginning of test sessions, with an additional 10-min blackout at the beginning of each session for a total of 60 min of pretreatment time. This pretreatment time was selected for two reasons: JZL195 produces a pronounced effect on motor behavior in rats after 60 min, (Seillier et al., 2014) and although URB597 has a rapid 
onset (approximately $15 \mathrm{~min}$ ), the long duration of its effects on brain anandamide levels and rectal temperature (Piomelli et al., 2006) placed a 60-min pretreatment time well within the suitable range for capturing effects of both drugs and allowed for a constant pretreatment time across rats and conditions. URB597 and JZL195 were purchased from Cayman Chemical.

\section{Procedure}

Lever-press training. At the beginning of each lever-press training session, both levers were extended into the chamber and food pellets were delivered on a conjoint variable-time (VT) 60 s fixed-ratio (FR) 1 schedule of reinforcement. On this schedule, a food pellet was delivered an average of once every $60 \mathrm{~s}$ independent of responding, and also immediately following any lever-press response. Lever pressing did not affect delivery of pellets from the VT component of the schedule and each of these sessions terminated following 60 food-pellet deliveries. If lever pressing had not been acquired after five sessions, it was shaped by reinforcement of successive approximations. Lever-press shaping involved using a remote control to deliver food pellets while the experimenter observed the rat through the viewing hole in the operant-conditioning chamber. Initially, pellets were delivered for approaching closer and closer to the lever. Then, pellets were only delivered for touching the lever, first with either paw and then with both. Finally, pellets were only delivered for full lever presses, and this continued until a minimum of 20 pellets were delivered for lever pressing. After lever-press acquisition, an FR 1 schedule of reinforcement alternating between levers was implemented. Alternating FR 1 sessions consisted of one lever extending into the chamber with a cue light illuminated over it. A response on this lever resulted in the delivery of a single food pellet. The FR 1 contingency and cue light alternated between the left and right levers after every five responses with each session lasting 
until 40 pellets had been delivered. Alternating FR 1 sessions continued until lever pressing was consistent on both levers across sessions.

Delay-discounting procedure. Following lever-press training, a delay-discounting procedure was implemented. Sessions began with a 10-min blackout. Each session consisted of 40 trials separated into five blocks, with a new trial beginning every $100 \mathrm{~s}$. As a result of this procedure, the inter-trial intervals (ITIs) varied in duration across each trial, depending on response latency and reinforcer delay. Each block began with two forced-exposure trials in which lever pressing produced the consequences for each choice available during that block. During each forced-exposure trial, the houselight was illuminated and a single randomly determined lever was extended into the chamber with its respective cue light illuminated. The lever retracted if a response was made, its respective cue light darkened, and either a single food pellet was delivered immediately or three food pellets were delivered after the programmed delay. Next, a second forced-exposure trial occurred in which the other lever was extended and its respective cue light was illuminated. A response on this lever was followed by similar consequences as in the initial forced-exposure trial (e.g., lever retracted, cue light darkened, and either the immediate or delayed food pellets were delivered). Following the forced-exposure trials, six free-choice trials occurred. Both levers were extended for free-choice trials and both cue lights were illuminated. Both consequences were available concurrently during free-choice trials, and a response on a lever resulted in either the smaller or the larger reinforcer being delivered, with the position of the lever for the larger reinforcer counterbalanced across rats. When a smaller reinforcer was delivered, the houselight flashed once as the food pellet was dispensed into the food trough. When a larger reinforcer was delivered, the houselight remained on for the duration of the delay, flashed three times as the three pellets were dispensed into the 
food trough, and then remained off for the remainder of the trial. If a response was not made within 30 s of a trial onset, that trial would be recorded as an omission, the lever(s) would retract, the cue light(s) and houselight would darken, and a 70-s ITI would begin. If six or more omissions occured on free-choice trials, the data from that session were excluded from analyses.

Baseline training. In order to establish discrimination of reinforcer amounts, baseline training began with consequences for pressing either lever delivered after a 0-s delay. Delays to the larger reinforcer were then increased across blocks. The delay to the smaller reinforcer was always 0 s. The series of delays to the larger reinforcer was $0,10,20$, 40, and 60 s across blocks. The delay series was presented such that in the first block, the delay to the larger reinforcer and the smaller reinforcer was always $0 \mathrm{~s}$. In the second block, the larger reinforcer was delivered after a delay of $10 \mathrm{~s}$. In the third block, the larger reinforcer was delivered after a delay of $20 \mathrm{~s}$. This procedure continued until all five delays had been presented, one in each block. Sessions terminated after 40 trials, of which, 10 were forced-choice trials and the remainder free choice trials.

A minimum of 10 baseline sessions were conducted and baseline sessions continued until stability was observed. Stability criteria were defined as the absence of increasing or decreasing trends in the total number of larger-reinforcer choices during free-choice trials across the last five sessions, less than $20 \%$ variation from the grand mean in the total number of larger-reinforcer choices during each of the last five sessions, and a minimum of $80 \%$ larger-reinforcer choices in the 0 -s delay block. When responding reached stability, a 0-s probe session was conducted during which all delay values were set to zero in order to test for discrimination of reinforcer magnitude (Cardinal et al., 2000; Diller, Saunders, \& Anderson, 2008). Additional probe sessions were conducted as needed throughout the experiment if there was any evidence that 
reinforcer magnitude was not controlling responding (e.g., near-exclusive responding on a single lever). This only occurred for one rat, which was excluded due to near-exclusive responding on the lever associated with the larger reinforcer, even after the position of that lever was switched.

Acute administration of URB597 or JZL195. Once baseline responding reached stability and initial probe sessions had been conducted, the same procedure used to establish baseline delay-discounting functions was used to test the effects of URB597 and JZL195. Drug or vehicle was administered to all rats on Tuesdays and Fridays so that there was always a minimum of two days between injections. Control sessions occurred on Mondays and Thursdays. Wednesday sessions were identical to control sessions, but were not included in the calculations for determining if drug should be administered. Drug administration only occurred if largerreinforcer choice was $80 \%$ or higher during the first free-choice block of the control session immediately prior to the test day. On any test day for which drug-administration criteria were not met, those sessions were identical to control sessions and drug testing did not resume until drugadministration criteria were met. Vehicle was administered for at least two sessions prior to drug administration in order to allow for habituation to the injection procedure and to determine any vehicle-induced effects on behavior. Drug doses were administered in both ascending and descending sequences, with an additional administration of vehicle occurring between each sequence. Each dose of each drug was tested at least twice, except for $3.0 \mathrm{mg} / \mathrm{kg}$ URB597, with order of presentation counterbalanced such that four rats received URB597, and four received JZL195 first. The $3.0 \mathrm{mg} / \mathrm{kg}$ dose of URB597 was not repeated after observing no change in behavior following its initial administration. 


\section{Data Analysis}

The primary dependent variable was the percentage of larger-reinforcer choice at each delay value. Delay-discounting functions were constructed for each rat as percent-largerreinforcer choice across each delay value in the terminal delay series. Secondary dependent variables included indifference points and AUC. A nonlinear regression was fitted to the choice data from the baseline condition and indifference points were calculated by interpolating the delay value at which choice for the larger reinforcer was 50\% (e.g., Anderson \& Woolverton, 2005). AUC was calculated by drawing vertical lines from each data point to the normalized xaxis and the combined area of the trapezoids drawn by these vertical lines was divided by the total area of the graph (Myerson et al., 2001). An analysis of variance (ANOVA) was conducted to assess the effects of each drug on percent-larger-reinforcer choice at each delay value.

Additional ANOVAs were conducted to assess the effect of each drug on AUC and indifference points. Smaller percentages of larger-reinforcer choice, shorter indifference points, and lower AUC are all indicative of increased impulsive choice.

\section{Results}

Mean percentage of larger-reinforcer choice as a function of increasing delays for all rats is shown in Figure 1, with URB597 data in the top panel and JZL195 data in the bottom panel. A significant main effect of trial block was found for vehicle data, $F(2.54,50.83)=63.46$, which indicates that choice for the larger reinforcer occurred less often as delay values increased (delay discounting) when no drug was present. Note that one rat was excluded from the experiment due to consistent and exclusive choice for the larger reinforcer during baseline.

A series of two-way repeated-measures ANOVAs were conducted to compare effects of each dose of URB597 (Figure 1, top panel) on percent-larger-reinforcer choice during each 
block. There was no main effect of any dose of URB597. A statistically significant interaction between dose and block was observed at the $0.3 \mathrm{mg}$ dose, $F(3.05,60.99)=1.75, p<.01$. A simple effects analysis showed that percent larger-reinforcer choice was higher during the 40-s block $(p=.018)$.

Figure 2 shows mean larger-reinforcer choice data for individual rats for vehicle and URB597. Although not statistically significant, URB597 generally increased choice for the larger reinforcer during the 20- and 40-s blocks for Rat 2, but decreased choice for the larger reinforcer during some blocks for Rats 5, 7, and 8. Responding was almost completely unchanged relative to vehicle by URB597 for Rats 3, 4, and 6.

A series of two-way repeated-measures ANOVAs were conducted to compare effects of each dose of JZL195 (Figure 1, bottom panel) on percent larger-reinforcer choice during each block. There was no main effect of any dose of JZL195. A statistically significant interaction between dose and block was observed at the $7.5 \mathrm{mg}$ dose, $F(2.64,44.88)=6.52, p<.01$. A simple main effects analysis showed that percent larger-reinforcer choice was higher during the 0 -s block $(p=.002)$ and lower during the 60-s block $(p=.014)$.

Figure 3 shows mean larger-reinforcer choice data for individual rats for vehicle and JZL195. Disruptions to responding were apparent but unsystematic. At higher delay values, larger-reinforcer choice tended to increase relative to vehicle for Rat 4 with the $7.5 \mathrm{mg} / \mathrm{kg}$ dose, but was decreased during the first two blocks. A similar pattern was present in the responding of Rat 5 at the $7.5 \mathrm{mg} / \mathrm{kg}$ dose. Larger-reinforcer choice for Rat 7 was disrupted at all delay values at the 5.0 and $7.5 \mathrm{mg} / \mathrm{kg}$ doses, although not in a systematic direction. Larger-reinforcer choice for Rat 8 decreased at lower delay values and increased at higher delay values with doses of 5.0 
mg/kg JZL195, but was slightly reduced at all delay values for the $7.5 \mathrm{mg} / \mathrm{kg}$ dose. Responding was almost completely unchanged relative to vehicle by JZL195 for Rats 2, 3, and 6.

A one-way repeated-measures ANOVA was conducted to compare effects of each dose of JZL195 and URB597 on AUC, indifference points, omissions, and latency. No statistically significant effect of any dose of either drug was observed (data not shown). Similarly, differences in number of response omissions were not statistically significant between vehicle and drug days. Response latency increased following administration of $7.5 \mathrm{mg} / \mathrm{kg}$ of JZL195 (M $=171.29, S E=11.20)$ relative to vehicle $(M=95.12, S E=5.27)$.

Furthermore, additional visual analyses were conducted by selecting injection days when individual responding appeared to be altered and comparing those data with data from the days immediately preceding and following injection, as well as with the most recent vehicle injection rather than the average of all vehicle days. No differences in percent larger-reinforcer choice were evident that were not already visible in Figures 2 and 3.

\section{Discussion}

Neither URB597 nor JZL195 had a systematic effect on any measure of impulsivity (i.e., AUC, indifference points, percent larger-reinforcer choice), at any dose. There are several possible interpretations of these data. One is that the task used was not sensitive enough to capture effects of URB597 and only captured effects of JZL195 at the most extreme delay values. Another possibility is that some part of the procedure prevented the drugs from being biologically available, possibly due to an error either in their preparation or administration. A third possibility is that the conditions required for an effect of one or both drugs on delay discounting to be observed were not met in the present experiment. Finally, it is also possible 
that cannabinoid enzyme inhibitors or the endocannabinoid system in general are not involved in delay discounting. Each of these possibilities will be discussed in greater detail.

Responding was disrupted for some rats to some extent at several doses of both drugs. While not statistically significant, these disruptions may represent a behaviorally significant effect that the present procedure was not sensitive enough to fully detect. Impulsivity may have been affected in ways that could have been seen with a different delay-discounting task, different parameters in the present task, or a different measure of impulsivity altogether. For instance, while strain differences have been observed between Lewis and Fischer 344 rats in delaydiscounting and other impulsivity-related tasks (e.g., Anderson \& Woolverton, 2005; Hamilton, Potenza, \& Grunberg, 2014), strain differences do not seem to affect probability discounting (Ozga-Hess, Vonder Haar, \& Anderson, unpublished).

Probability discounting is another form of impulsive choice (sometimes deemed "risky choice”), in which the larger reinforcer is delivered probabilistically rather than after a delay. In probability discounting, the impulsive choice would be selecting the larger reinforcer when the product of the probability of the larger reinforcer being delivered and the magnitude of the larger reinforcer are larger than the product of the same parameters of the smaller reinforce (e.g., choosing 3 pellets at 25\% probability of delivery is more impulsive than choosing 1 pellet with 100\% probability of delivery). While delay- and probability-discounting procedures are both thought to measure "impulsivity" in a choice paradigm, it has become increasingly clear in recent years that they are not identical processes. For example, smaller reinforcers are discounted more steeply in delay discounting, while the opposite is true in probability discounting (Estle, Green, Myerson, \& Holt, 2006). Furthermore, strain differences are seen between Fischer 344 and Lewis rats in delay discounting, but not probability discounting (Ozga-Hess, Vonder Haar, \& 
Anderson, unpublished). Probability discounting likely reflects a similar, although separate process from delay discounting. Therefore, it is possible that drug effects not observed in a delay-discounting paradigm could be seen in a probability-discounting procedure. Future research could examine this possibility by testing effects of URB597 and JZL195 in a probability-discounting paradigm.

Although there is no published research on enzyme inhibitors and probability discounting to date, many different cannabinoid drugs have been studied for their effects on various other impulsivity-related behaviors and tasks. The type of cannabinoid and the way impulsivity is being measured appear to be important determinants in whether a cannabinoid drug will affect responding. Ferland et al. (2018) found that THC and synthetic CB1 agonist WIN55,212-2 exerted modest effects on motor impulsivity, but not choice impulsivity in the rodent gambling task. In the same study, URB597 was found to exert no effect on any measure of impulsivity. Conversely, Khani et al. (2015) found that increased cannabinoid signaling in the OFC increased delay discounting but not discounting based on effort, while the inverse was true for the anterior cingulate cortex. Nonetheless, delay-discounting procedures identical to those used in the present study have been effective at detecting effects of numerous drugs including diazepam, nicotine, amphetamine, methylphenidate, and caffeine (Anderson \& Diller, 2010; Diller, et al., 2008; Huskinson \& Anderson, 2012; Krebs, et al., 2016; Slezak, \& Anderson, 2011).

The lack of statistically significant results suggests that it is possible that cannabinoid drugs produce no effect on delay discounting. However, given the disruptions to responding mentioned above and the mixed effects seen in prior research, it is more likely that they produce a less-than-robust effect that the present experiment was unable to detect for at least two possible reasons. One possibility is that individual differences in responding were washed out by the 
averaging of data across rats. Another possibility is that if responding shifted across time, the averaging of a relatively small number of data points across a relatively large time span (e.g., two administrations of a particular dose separated by a number of weeks) could have obscured a drug effect. To address the first possibility, percent larger-reinforcer choice for individual rats was visually inspected after being plotted as a function of delay for each dose of each drug (see Figures 2 and 3). Responding appeared to be disrupted at some delay values for some rats and some doses (e.g., Rat 7 in Figures 2 and 3). Still, drug and vehicle data were collected over a period of approximately three months, which left open the possibility that gradual shifts in responding and averaging of multiple data points could have obscured a drug effect. Visual analysis did not provide any more information about changes in responding at a more molecular level. Unfortunately, the ability of most statistical methods to detect an effect is based on the number of subjects or observations, and the ANOVA family of analyses is likely the most wellsuited method for analyzing data as they were collected in the present experiment. Future research should be designed with the ability to detect small effect sizes in mind (e.g., larger sample size, more drug administrations).

A clear inhibitory effect of JZL195 on motor behavior in rats has been demonstrated in past studies, but responding in the present study was largely unaffected (e.g., Long et al., 2009; Seillier et al., 2014). While motor behavior was not directly recorded in the present study, omissions were were not affected by administration of any dose of JZL195 and latency to respond was only affected at the $7.5 \mathrm{mg} / \mathrm{kg}$ dose. This leaves open the possibility that an error in the process of drug preparation or administration occurred and the drugs were not bioavailable or active in-vivo. Still, the statistically significant disruption of responding observed following drug administration on some days for some rats at some delay values suggests that the drugs were 
bioavailable but did not produce a robust behavioral effect (see individual graphs of percent larger-reinforcer choice for Rats 4, 5, 7, and 8 in Figure 3).

To rule out the possibility that the drugs were not bioavailable, a behavioral task in which JZL195 and URB597 are known to produce effects could be used to ensure that the drugs were behaviorally active, regardless of their effects on delay-discounting. Although there is a paucity of behavior-analytic research on cannabinoid drugs, there is a standard "tetrad" of physiological effects that are produced by CB1 agonists and some enzyme inhibitors (e.g., Fride, Perchuk, Hall, Uhl, \& Onaivi, 2006; Long et al., 2009). These effects include analgesia, catalepsy, hypomotility, and hypothermia. Specifically, JZL195 has been shown to produce all of these effects in mice and at least hypomitility in rats (Bedse et al., 2018; Limebeer et al., 2013; Long et al., 2009; Seiller et al., 2014). URB597 has been shown to produce analgesia, but not catalepsy, hypomotility, or hypothermia in rats and mice (Piomelli et al., 2006).

Administering part or all of the tetrad tests would be a way to ensure that the drug vehicle, pretreatment time, and route of administration were not the reason for any lack of effect on behalf of the drugs. In the present study, vehicle preparation, pretreatment time, and route of administration were accounted for and informed by prior experiments (Marco et al., 2007; Piomelli et al., 2006; Seillier et al., 2014), but replication of a reliable drug effect (any of the four tetrad effects for JZL195, analgesia for URB597) under conditions identical to those used in the present study would provide more certainty that these drugs are biologically active but do not affect impulsive choice.

Marco et al., (2007) found that URB597 significantly reduced delay discounting in rats, but only in rats that had elevated baseline levels of impulsivity following maternal separation early in life. Similarly, while there is little evidence for effects of cannabinoids on impulsivity in 
humans in general (McDonald et al., 2003; Metrik et al., 2013), a modest improvement in motor impulsivity was observed in ADHD patients following treatment with a THC/CBD mixture (Cooper et al., 2017). These baseline- or impairment-dependent effects are also seen in studies where URB597 alleviates or prevents cognitive deficits, (e.g., responding in a passive avoidance test, Hasanein \& Ghafari-Vahed, 2016), but has no effect on unimpaired animals.

Another factor that may affect when enzyme inhibitors such as JZL195 and URB597 alter behavior is the amount of endogenous cannabinoids present at the time of measurement. Because endogenous cannabinoids are synthesized on demand (Pertwee, 2004) and are only present when needed, inhibiting their metabolic enzymes should only produce an effect if there are already endogenous cannabinoids present whose metabolism could be inhibited or delayed. Evidence of this relation can be seen when exogenous AEA enhances anti-nausea effects of URB597 (Cross-Mellor, Ossenkopp, Piomelli, \& Parker, 2007) or when URB597 enhances the hypothermic response produced by exogenous AEA in wild-type mice, but not in mice genetically altered to lack FAAH (Fegley et al., 2005). Inhibition of the metabolism of chemicals that are not present or are already exerting their maximal effect is one scenario in which enzyme inhibitors could produce no change in behavior.

Another possibility is that neither the specific delay-discounting procedure, the method of administration, nor the conditions under which the experiment were conducted are to blame for the lack of effect. One could argue that the endocannabinoid system, which is the target of the drugs used in the present study, is simply not involved in delay discounting. This is unlikely for several reasons. First, the findings of prior research, although mixed, do demonstrate some relation between CB1 activity and delay discounting. Second, as mentioned above, the endocannabinoid system modulates the activity of other neurotransmitter systems known to 
affect delay discounting. Third, given the proliferation of CB1 receptors in the central nervous system (particularly in areas already known to be involved in delay discounting), it is unreasonable to assume that those receptors do not also play a role in delay discounting.

The relation between endogenous cannabinoid agonists, enzyme inhibitors, cannabinoid receptor activity, and behavioral outcomes is complex. A full understanding of the effects of enzyme inhibitors on behavior, to which the present study was designed to contribute, would benefit from first understanding how cannabinoids in general affect responding on simple schedules of reinforcement and punishment. From these baselines, environmental manipulations could be made (e.g., experimentally induced cognitive deficits, additional pharmacological manipulations, genetic alterations) and comparisons drawn. To examine the differences in behavioral effects between agonists and enzyme inhibitors, similar comparisons and manipulations could be made. While the present experiment was designed to contribute to the sparse literature on cannabinoid enzyme inhibitors and impulsivity, beginning with an understanding of how these drugs affect responding on simple schedules would likely be very useful in informing studies on more complex forms of responding, such as impulsivity.

Future studies might also benefit from knowledge of cannabinoids and simple schedules by providing a baseline with which to determine if a drug is behaviorally active. In the present study, neither drug affected omissions or latencies consistently. Given that there is empirical evidence that JZL195 should have observable motoric effects at the doses used in the present study (Long et al., 2009; Seillier et al., 2014), a lack of systematic changes in omissions or latencies suggests that either the delay-discounting task was insensitive to the behavioral changes that occurred, or no behavioral changes occurred. If the task was not sensitive enough, knowledge of how cannabinoids affect responding on simple schedules could inform the 
parameters of more complex procedures to increase their sensitivity. For example, if a drug effect was only apparent at higher values of a differential-reinforcement-of-low-rates (DRL) schedule of reinforcement, that information might inform the delay values used in a delaydiscounting procedure. If there was sufficient reason to believe the sensitivity of the task was not to blame and there was still no effect on responding, and the drugs were determined to be bioavailable, then that would imply that measures used in previous research do not correspond with the operant measures discussed here.

In summary, despite effects of cannabinoid drugs on many forms of behavior found in other experiments, no effect of URB597 or JZL195 on delay discounting was found in the present experiment. The reasons for a lack of statistically significant effects could be due to a number of limitations previously discussed. Before a conclusion can be drawn that enzyme inhibitors do not affect delay discounting, research should be conducted to determine if a different ask can reveal drug effects, to ensure that the drugs are bioavailable as prepared and administered in the present study, and to clarify what conditions are necessary for an effect to be observed (e.g., pre-existing deficits in responding, altered levels of endogenous cannabinoids, maternal deprivation). 


\section{References}

Adamson Barnes, N. S., Mitchell, V. A., Kazantzis, N. P., \& Vaughan, C. W. (2016). Actions of the dual FAAH/MAGL inhibitor JZL195 in a murine neuropathic pain model. British Journal of Pharmacology, 173(1), 77-87. http://doi.org/10.1111/bph.13337

Adriani, W., Caprioli, A., Granstrem, O., Carli, M., \& Laviola, G. (2003). The spontaneously hypertensive rat as an animal model for ADHD: evidence for impulsive and nonimpulsive subpopulations. Neuroscience and Biobehavioral Reviews, 27(7), 639-651. http://doi.org/10.1016/j.neubiorev.2003.08.007

Ahn, K., McKinney, M. K., \& Cravatt, B. F. (2008). Enzymatic pathways that regulate endocannabinoid signaling in the nervous system. Chemical Reviews, 108(5), 1687-1707.

Ainslie, G. (1975). Specious reinforcer: a behavioral theory of impulsiveness and impulse control. Psychological Bulletin, 82(4), 463-496. http://doi.org/10.1037/h0076860

Ainslie, G. (1974). Impulse control in pigeons. Journal of the Experimental Analysis of Behavior, 21(3), 485-9. http://doi.org/10.1901/jeab.1974.21-485

Alessi, S. M., \& Petry, N. M. (2003). Pathological gambling severity is associated with impulsivity in a delay discounting procedure. Behavioural Processes, 64(3), 345-354. http://doi.org/10.1016/S0376-6357(03)00150-5

Alvarez-Jaimes, L. J., \& Palmer J. A. (2011). The role of endocannabinoids in pain modulation and the therapeutic potential of inhibiting their enzymatic degradation. Current Pharmaceutical Biotechnology, 12(10), 1644-1659

Amlung, M., Vedelago, L., Acker, J., Balodis, I., \& Mackillop, J. (2016). Steep delay discounting and addictive behavior: A meta-analysis of continuous associations. Addiction, 51-62. http://doi.org/10.1111/add.13535 
Anderson, K. G., \& Diller, J. W. (2010). Effects of acute and repeated nicotine administration on delay discounting in Lewis and Fischer 344 rats. Behavioral Pharmacology, 21(8), 654764. http://doi.org/10.1097/FBP.0b013e328340a050

Anderson, K. G., \& Woolverton, W. L. (2005). Effects of clomipramine on self-control choice in Lewis and Fischer 344 rats. Pharmacology Biochemistry and Behavior, 454(1), 42-54. http://doi.org/10.1016/j.pbb.2004.11.015

Anderson, W. B., Gould, M. J., Torres, R. D., Mitchell, V. A., Vaughan, C. W. (2014). Actions of dual FAAH/MAGL inhibitor JZL195 in a murine inflammatory pain model. Neuropharmacology, 81, 224-230. http://doi.org/10.1016/j.neuropharm.2013.12.018

Basar, K., Sesia, T., Groenegewen, H., Steinbusch, H.W.M., Visser-Vandewalle, W., \& Temel, Y. (2010). Nucleus accumbens and impulsivity. Progress in Neurobiology, 92(4), 533-557. http://dx.doi.org/10.1016/j.pneurobio.2010.08.007

Bedse, G., Bluett, R. J., Patrick, T. A., Romness, N. K., Gaulden, A. D., Kingsley, P. J.,...\& Patel, S. (2018). Therapeutic endocannabinoid augmentation for mood and anxiety disorders: Comparative profiling of FAAH, MAGL, and dual inhibitors. Translation Psychiatry, 8(1), 92. http://doi.org/10.1038/s41398-018-0141-7

Bickel, W. K., Odum, A. L., \& Madden, G. J. (1999). Impulsivity and cigarette smoking: Delay discounting in current, never, and ex-smokers. Psychopharmacology, 146(4), 447-454. http://doi.org/10.1007/PL00005490

Bizot, J., Le Bihan, C., Puech, A.J., Hamon, M., \& Thiébot M. (1999). Serotonin and tolerance to delay of reward in rats. Psychopharmacology, 146(4), 400-412.

Bortolato, M., Mangieri, R. A., Fu, J., Kim, J. H., Arguello, O., Duranti, A., Mor, M., Tarzia, G., \& Piomelli, D. (2007). Antidepressant-like activity of the fatty acid amide hydrolase 
inhibitor URB597 in a rat model of chronic mild stress. Biological Psychiatry, 62(10), 1103-1110. http://doi.org/10.1016/j.biopsych.2006.12.001

Brown, A.J. (2007). Novel cannabinoid receptors. British Journal of Pharmacology, 152(5), 567575. https://doi.org/10.1038/sj.bjp.0707481

Cardinal, R. N., Robbins, T. W., \& Everitt, B. J. (2000). The effects of d-amphetamine, chlordiazepoxide, $\alpha$-flupenthixol and behavioural manipulations on choice of signalled and unsignalled delayed reinforcement in rats. Psychopharmacology, 152(4), 362-375. http://doi.org/10.1007/s002130000536

Cardinal, R. N. (2006). Neural systems implicated in delayed and probabilistic reinforcement. Neural Networks, 19(8), 1277-1301. http://doi.org/10.1016/j.neunet.2006.03.004

Cardinal, R. N., Pennicott, D. R., Sugathapala, C. L., Robbins, T. W., \& Everitt, B. J. (2001). Impulsive choice induced in rats by lesions of the nucleus accumbens core. Science, 292(5526), 2499-2501. http://doi.org/10.1126/science.1060818

Carlisi, C. O., Chantiluke, K., Norman, L., Christakou, A., Barrett, N., Giampietro, V., Brammer, M., Simmons, A., \& Rubia, K. (2016). The effects of acute fluoxetine administration on temporal discounting in youth with ADHD. Psychological Medicine, 1197-1209. http://doi.org/10.1017/S0033291715002731

Castellanos-Ryan, N., Brière, F. N., Banaschewski, T., Bromberg, U., Büchel, C., Flor, H., Frouin, V., Garavan, H., Paus, T., Rietschel, M., Smolka, M., Robbins, T., Whelan, R., Schumann, G., \& Conrod, P. (2016). The Structure of Psychopathology in Adolescence and Its Common Personality and Cognitive Correlations

Cooper, R. E., Williams, E., Seegobin, S., Tye, C., Kuntsi, J., \& Asherson, P. (2017). Cannabinoids in attention-deficit/hyperactivity disorder: A randomised-controlled trial. 
European Neuropsychopharmacology, 27(8), 295-808.

http://doi.org/0.1016/j.euroneuro.2017.05.005

Cross-Mellor, S. K., Ossenkopp, K. P., Piomelli, D., \& Parker, L. A. (2007). Effects of the

FAAH inhibitor, URB597, and anandamide on lithium-induced taste reactivity responses:

A measure of nausea in the rat. Psychopharmacology, 190(2), 135-143.

http://doi.org/10.1007/s00213-006-0589-7

Darna, M., Chow, J. J., Yates, J. R., Charnigo, R. J., Bechmann, J. S., Bardo, M. T., Dwoskin, L. P. (2015). Role of serotonin transporter function in rat orbitofrontal cortex in impulsive choice. Behavioural Brain Research, 293, 134 - 142.

Dilller, J. W., Saunders, B. T., \& Anderson, K. G. (2008). Effects of acute and repeated administration of caffeine on temporal discounting in rats. Pharmacology, Biochemistry, and Behavior, 89(4), 546-555. http://doi.org/10.1016/j.pbb.2008.02.008

Di Marzo, V. \& De Petrocellis, L. (2012). Why do cannabinoid receptors have more than one endogenous ligand? Philosophical transactions of the Royal Society B, 367(1607). http://doi.org/10.1098/rstb.2011.0382

Diller, J. W., Saunders, B. T., \& Anderson, K. G. (2008). Effects of acute and repeated administration of caffeine on temporal discounting in rats. Pharmacology Biochemistry and Behavior, 89(4), 546-555. http://doi.org/10.1016/j.pbb.2008.02.008

Dom, G., De Wilde, B., Hulstijn, W., Van Den Brink, W., \& Sabbe, B. (2006). Behavioural aspects of impulsivity in alcoholics with and without a cluster-B personality disorder. Alcohol and Alcoholism, 41(4), 412-420. http://doi.org/10.1093/alcalc/agl030 
Dove Pettit, D. A., Harrison, M. P., Olson, J. M., Spencer, R. F., \& Cabral, G. A. (1998). Journal of Neuroscience Research, 51(3), 391-402. http://doi.org/ 10.1002/(SICI)10974547(19980201)51:3<391::AID-JNR12>3.0.CO;2-A

El-Alfy, A. T., Ivey, K., Robinson, K., Ahmed, S., Radwan, M., Slade, D., Khan I., ElSohly, M., \& Ross, S. (2010). Antidepressant-like effect of delta-9-tetrahydrocannabinol and other cannabinoids isolated from Cannabis sativa L. Pharmacology, Biochemistry, and Behavior, 95(4), 434-42. http://doi.org/10.1016/j.pbb.2010.03.004

Estle, S. J., Green, L., Myerson, J., \& Holt, D. D. (2006). Differential effects of amount on temporal and probability discounting. Memory and Cognition, 34(4), 914-928. http://doi.org/10.3758/BF03193437

Evenden, J. L., \& Ryan, C. N. (1996). The pharmacology of impulsive behaviour in rats: the effects of drugs on response choice with varying delays of reinforcement. Psychopharmacology, 128(2), 161-170. http://doi.org 10.1007/s002130050121

Evenden, J. L., \& Ryan, C. N. (1999). The pharmacology of impulsive behaviour in rats VI: the effects of ethanol and selective serotonergic drugs on response choice with varying delays of reinforcement. Psychopharmacology, 146(4), 413-421. http://doi.org/10.1007/PL00005486

Fride, E., Perchuk, A., Hall, F. S., Uhl, G. R., \& Onaivi, E. S. (2006). Behavioral methods in cannabinoid research. Methods in Molecular Medicine, 123, 269-90.

Giuffrida, A., \& Seillier, A. (2012). New insights on endocannabinoid transmission in psychomotor disorders. Progress in Neuro-Psychopharmacology and Biological Psychiatry, 38(1), 51-58. http://doi.org/10.1016/j.pnpbp.2012.04.002 
Govaerts, S. J., Hermans, E., \& Lambert, D. M. (2004). Comparison of cannabinoid ligands affinities and efficacies in murine tissues and transfected cells expressing human recombinant cannabinoid receptors. European Journal of Pharmaceutical Sciences, 23(3), 233-243. https://doi.org/10.1016/j.ejps.2004.07.013

Guindon, J. (2016). A novel inhibitor of endocannabinoid catabolic enzymes sheds light on behind the scene interplay between chronic pain, analgesic tolerance, and heroin dependence. Neuropharmacology, 114, 11-14. http://doi.org/10.1016/j.neuropharm.2016.11.018

Hamilton, K. R., Potenza, M. N., \& Grunberg, N. E. (2014). Lewis rats have greater response impulsivity than Fischer rats. Addictive Behaviors, 39(11), 1565-1572. http://doi.org/10.1016/j.addbeh.2014.02.008

Hasanein, P., \& Ghafari-Vahed, M. (2016). Fatty acid amide hydrolase inhibitor URB597 prevented tolerance and cognitive deficits induced by chronic morphine administration in rats. Behavioural Pharmacology, 27(1), 37-43.

http://doi.org/10.1097/FBP.0000000000000179

Hasanein, P., \& Teimuri Far, M. (2015). Effects of URB597 as an inhibitor of fatty acid amide hydrolase on WIN55, 212-2-induced learning and memory deficits in rats. Pharmacology Biochemistry and Behavior, 131, 130-135. http://doi.org/10.1016/j.pbb.2015.02.007

Heerey, E. A., Robinson, B. M., McMahon, R. P., \& Gold, J. M. (2007). Delay discounting in schizophrenia. Cognitive Neuropsychiatry, 12(3), 213-21. http://doi.org/10.1080/13546800601005900

Herkenham, M., Lynn, A.B., Little, M.D., Johnson, M.R., Melvin, L.S., De Costa, B.R., \& Rice, K.C. (1990). Cannabinoid receptor localization in brain. Proceedings of the National 
Academy of Sciences of the United States of America, 87, 1932 - 1936. http://doi.org/10.1073/pnas.87.5.1932

Huskinson, S. L., Krebs, C. A., \& Anderson, K.G. (201 $\quad$ 2). Strain differences in delay discounting between Fisher and Lewis 344 rats and baseline and following acute and chronic d-amphetamine. Pharmacology Biochemistry and Behavior, 101(3), 403-416. http://doi.org/10.1016/j.pbb.2012.02.005

Huskinson, S. L., \& Anderson, K. G. (2012). Effects of acute and chronic administration of Diazepam on delay discounting in Lewis and Fischer 344 rats. Behavioral Pharmacology, 23(4), 315-330. http://doi.org/10.1097/FBP.0b013e3283564da4

Jayamanne, A., Greenwood, R., Mitchell, V. a, Aslan, S., Piomelli, D., \& Vaughan, C. W. (2006). Actions of the FAAH inhibitor URB597 in neuropathic and inflammatory chronic pain models. British Journal of Pharmacology, 147(3), 281-288.

http://doi.org/10.1038/sj.bjp.0706510

Justinova, Z., Mangieri, R. A., Bortolato, M., Chefer, S. I., Alexey, G., Clapper, J. R., King, A. R., Redhi, G. H., Yasar, S., Piomelli, D., \& Goldberg, S. R. (2009). Fatty acid amide hydrolase inhibition heightens anandamide signaling without producing reinforcing effects in primates, 64(11), 930-937. http://doi.org/10.1016/j.biopsych.2008.08.008

Kemp, A. M., Clark, M. S., Dobbs, T., Galli, R., Sherman, J., \& Cox, R. (2016). Top 10 facts you need to know about synthetic cannabinoids: Not so nice spice. American Journal of Medicine, 129(3), 240-244. http://doi.org/10.1016/j.amjmed.2015.10.008

Kirby, K. N., Petry, N. M., \& Bickel, W. K. (1999). Heroin addicts have higher discount rates for delayed reinforcers than non-drug-using controls. Journal of Experimental Psychology: General, 128(1), 78-87. http://doi.org/10.1037/0096-3445.128.1.78 
Krebs, C. A., Reilly, W. J., \& Anderson, K. G. (2016). Reinforcer magnitude affects delay discounting and influences effects of d-amphetamine in rats. Behavioral Processes, 130, 39-45. http://doi.org/10.1016/j.beproc.2016.07.004

Kwilasz, A. J., Abdullah, R. A., Poklis, J. L., Lichtman, A. H., \& Negus, S. S. (2014). Effects of the fatty acid amide hydrolase inhibitor URB597 on pain-stimulated and pain-depressed behavior in rats. Behavioural Pharmacology, 25(2), 119-29. http://doi.org/10.1097/FBP.0000000000000023

Limebeer, C. L., Abdullah, R. A., Rock, E. M., Imhof, E., Wang, K., Lichtman, A. H., \& Parker, L. A. (2014). Psychopharmacology, 231(3), 603-12. http://doi.org/10.1007/s00213-013$3282-7$

Lloyd, K. E. (1994). Do As I Say, Not As I Do. The Behavior Analyst, 1(1), 131-139.

Long, J. Z., Li, W., Booker, L., Burston, J. J., Kinsey, S. G., Schlosburg, J. E.,... Cravatt, B. F. (2009). Selective blockade of 2-arachidonoylglycerol hydrolysis produces cannabinoid behavioral effects. Nature Chemical Biology, 5(1), 37-44. http://doi.org/10.1038/nchembio.129

López-Moreno, J. A., González-Cuevas, G., Moreno, G., \& Navarro, M. (2008). The pharmacology of the endocannabinoid system: Functional and structural interactions with other neurotransmitter systems and their repercussions in behavioral addiction. Addiction Biology, 13(2), 160-187. http://doi.org/10.1111/j.1369-1600.2008.00105.x

Manduca, A., Servadio, M., Campolongo, P., Palmery, M., Trabace, L., Vanderschuren, L. J. M. J., Cuomo, V., \& Trezza, V. (2014). Strain- and context-dependent effects of the anandamide hydrolysis inhibitor URB597 on social behavior in rats. European 
Neuropsychopharmacology, 24(8), 1337-1348.

http://doi.org/10.1016/j.euroneuro.2014.05.009

Marco, E. M., Adriani, W., Canese, R., Podo, F., Viveros, M. P., \& Laviola, G. (2007).

Enhancement of endocannabinoid signalling during adolescence: Modulation of impulsivity and long-term consequences on metabolic brain parameters in early maternally deprived rats. Pharmacology Biochemistry and Behavior, 86(2), 334-345. http://doi.org/10.1016/j.pbb.2006.10.006

McDonald, J., Schleifer, L., Richards, J. B., \& de Wit, H. (2003). Effects of THC on behavioral measures of impulsivity in humans. Neuropsychopharmacology, 28(7), 1356-65. http://doi.org/10.1038/sj.npp.1300176

Mclaughlin, P. J., Jagielo-Miller, J. E., Plyler, E. S., Schutte, K. K., Vemuri, V. K., \& Makriyannis, A. (2017). Differential effects of cannabinoid CB1 inverse agonists and antagonists on impulsivity in male Sprague Dawley rats: identification of a possibly clinically relevant vulnerability involving the serotonin 5HT 1A receptor. Psychopharmacology, 234, 1029-1043. http://doi.org/10.1007/s00213-017-4548-2

Metrik, J., Kahler, C. W., Reynolds, B., McGeary, J. E., Monti, P. M., Haney, M., de Wit, H., \& Rohsenow, D. J. (2012). Balanced placebo design with marijuana: Pharmacological and expectancy effects on impulsivity and risk taking. Psychopharmacology, 223(4), 489-99. http://doi.org/10.1007/s00213-012-2740-y

Mitchell, S. H., Wilson, V. B., \& Karalunas, S. L. (2015). Comparing hyperbolic, delay-amount sensitivity and present-bias models of delay discounting. Behavioural Processes, 114, 52-62. http://doi.org/10.1016/j.beproc.2015.03.006 
Mobini, S., Chiang, T.K., Ho, M.Y., Bradshaw, C.M., \& Szabadi, E. (2000). Effects of central 5hydroxytryptamine depletion on sensitivity to delayed and probabilistic reinforcement. Psychopharmacology, 152(4), 390 - 397.

Moody, L., Franck, C., \& Bickel, W. K. (2016). Comorbid depression, antisocial personality, and substance dependence: Relationship with delay discounting. Drug and Alcohol Dependence, 160, 190-196. http://doi.org/10.1016/j.drugalcdep.2016.01.009

Moreira, F. A., Jupp, B., Belin, D., \& Dalley, J. W. (2015). Endocannabinoids and striatal function: implications for addiction-related behaviours. Behavioural Pharmacology, 26(1-2), 59-72. http://doi.org/10.1097/FBP.0000000000000109

Moschak, T.M., \& Mitchell, S.H. (2014). Partial inactivation of nucleus accumbens core decreases delay discounting in rats without affecting sensitivity to delay or magnitude. Behavioural Brain Research, 268, 159-168. http://doi.org/10.1016/j.bbr.2014.03.044

Myerson, J., Green, L., \& Warusawitharana, M. (2001). Area under the curve as a measure of discounting. Journal of the Experimental Analysis of Behavior, 76(2), 235-243. http://doi.org/10.1901/jeab.2001.76-235

Negus, S. S., \& Miller, L. L. (2014). Intracranial self-stimulation to evaluate abuse potential of drugs. Pharmacological Reviews, 66(3), 869-917. http://doi.org/10.1124/pr.112.007419

NIDA (2017). Marijuana. (2017, March 21). Retrieved from https://www.drugabuse.gov/publications/drugfacts/marijuana

Odum, A. L. (2011). Delay discounting: I'm a k, you're a k. Journal of the Experimental Analysis of Behavior, 96(3), 427-439. http://doi.org/10.1901/jeab.2011.96-423 
Ozga-Hess, J. E., Vonder Haar, C., \& Anderson, K. G. (unpublished). Differential effects of $d$ amphetamine and atomoxetine on risk-based decision-making of Lewis and Fischer 344 rats.

Pacher, P. Bàtkai, S., \& Kunos, G. (2006). Pharmacological Reviews, 58(3), 389-462. http://doi.org/10.1038/jid.2014.371

Pattij, T., Janssen, M.C.W., Schepers, I., Gonzalez-Cuevas, G., de Vries, T.J., \& Schoffelmeer, A.N.M. (2007). Effects of the cannabinoid CB1 receptor antagonist rimonabant on distinct measures of impulsive behavior in rats. Psychopharmacology, 193, 85-96. http://doi.org/10.1007/s00213-007-0773-4

Perry, J. L., Stairs, D. J., \& Bardo, M. T. (2008). Impulsive choice and environmental enrichment: Effects of d-amphetamine and methylphenidate. Behavioural Brain Research, 193(1), 48-54. http://doi.org/10.1016/j.bbr.2008.04.019

Pertwee, R. (Ed.). (2004). Cannabinoids. Germany: Springer-Verlag Berlin Heidelberg.

Piomelli, D., Giorgio, T., Duranti, A., Tontini, A., Mor, M., Compton, T.R., Dasse, O., Monaghan, E.P., Parrott, J.A., \& Putman, D. (2006). CNS Drug Reviews 12(1), 21-38. http://doi.org/10.1111/j.1527-3458.2006.00021.x

Rachlin, H., \& Green, L. (1972). Commitment, choice and self-control. Journal of the Experimental Analysis of Behavior, 17(1), 15-22. http://doi.org/10.1901/jeab.1972.17-15

Reggio, P.H. (Ed.). (2009). The Cannabinoid Receptors. New York, NY: Humana Press.

Reggio, P. H. (2010). Endocannabinoid binding to the cannabinoid receptors: what is known and what remains unknown. Current Medicinal Chemistry, 17(14), 1468-86. http://doi.org/10.2174/092986710790980005 
Rogers, R. D., Moeller, F. G., Swann, A. C., \& Clark, L. (2010). Recent research on impulsivity in individuals with drug use and mental health disorders: Implications for alcoholism. Alcoholism: Clinical and Experimental Research. http://doi.org/10.1111/j.15300277.2010.01216.x

Seillier, A., Aguilar, D. D., \& Giuffrida, A. (2014). The dual FAAH/MAGL inhibitor JZL195 has enhanced effects on endocannabinoid transmission and motor behavior in rats as compared to those of the MAGL inhibitor JZL184. Pharmacology Biochemistry and Behavior, 153-159. http://doi.org/10.1038/jid.2014.371

Simmons, J.M., Minamimoto, T., Murray, E.A., \& Richmond, B.J. (2010). Selective ablations reveal that orbital and lateral prefrontal cortex play different roles in estimating predicted reward value. Journal of Neuroscience, 30(47), 15878-15887.

http://doi.org/10.1523/JNEUROSCI.1802-10.2010

Slezak, J. M., \& Anderson, K. G. (2012). Effects of acute and chronic methylphenidate on delay discounting. Pharmacology, Biochemistry, and Behavior, 99(4), 545-551. http://doi.org/10.1016/j.pbb.2011.05.027

Stunkard, A. J. (2009). The endogenous cannabinoid anandamide has effects on motivation and anxiety that are revealed by fatty acid amide hydrolase (FAAH) inhibition. Psychiatry: Interpersonal and Biological Processes, 162(3), 214-220. http://doi.org/10.1016/j.pestbp.2011.02.012

Tanno, T., Maguire, D. R., Henson, C., \& France, C. P. (2014). Effects of amphetamine and methylphenidate on delay discounting in rats: Interactions with order of delay presentation. Psychopharmacology, 231(1), 85-95. http://doi.org/10.1007/s00213-013$3209-3$ 
Vanderveldt, A., Oliveira, L., and Green, L. (2016). Delay discounting: Pigeon, rat, humandoes it even matter? Journal of Experimental Psychology of Animal Learning and Cognition, 42(2), 141-162. http://doi.org/10.1037/xan0000097

Wiehler, A., \& Peters, J. (2015). Reinforcer-based decision making in pathological gambling: The roles of risk and delay. Neuroscience Research. Elsevier Ireland Ltd and Japan Neuroscience Society. http://doi.org/10.1016/j.neures.2014.09.008.

Wilkerson, J. L., Ghosh, S., Mustafa, M., Abdullah, R. A., Niphakis, M. J., Cabrera, R., Maldonado, R. L., Cravatt, B., \& Lichtman, A. H. (2016). The endocannabinoid hydrolysis inhibitor SA-57: Intrinsic antinociceptive effects, augmented morphineinduced antinociception, and attenuated heroin seeking behavior in mice. Neuropharmacology, 114, 156-167. http://doi.org/10.1016/j.neuropharm.2016.11.015.

Wilson, V. B., Mitchell, S. H., Musser, E. D., Schmitt, C. F., \& Nigg, J. T. (2011). Delay discounting of reinforcer in ADHD: Application in young children. Journal of Child Psychology and Psychiatry, 52(3), 256-264. http://doi.org/10.1111/j.14697610.2010.02347.x.

Winstanley, C. A., Dalley, J. W., Theobald, D. E. H., \& Robbins, T. W. (2004). Fractionating impulsivity: contrasting effects of central 5-HT depletion on different measures of impulsive behavior. Neuropsychopharmacology, 29(7), 1331-1343. http://doi.org/10.1038/sj.npp.1300434.

Wiskerke, J., Stoop, N., Schetters, D., Schoffelmeer, A. N. M., \& Pattij, T. (2011). Cannabinoid CB1 Receptor Activation Mediates the Opposing Effects of Amphetamine on Impulsive Action and Impulsive Choice, 6(10). http://doi.org/10.1371/journal.pone.0025856. 

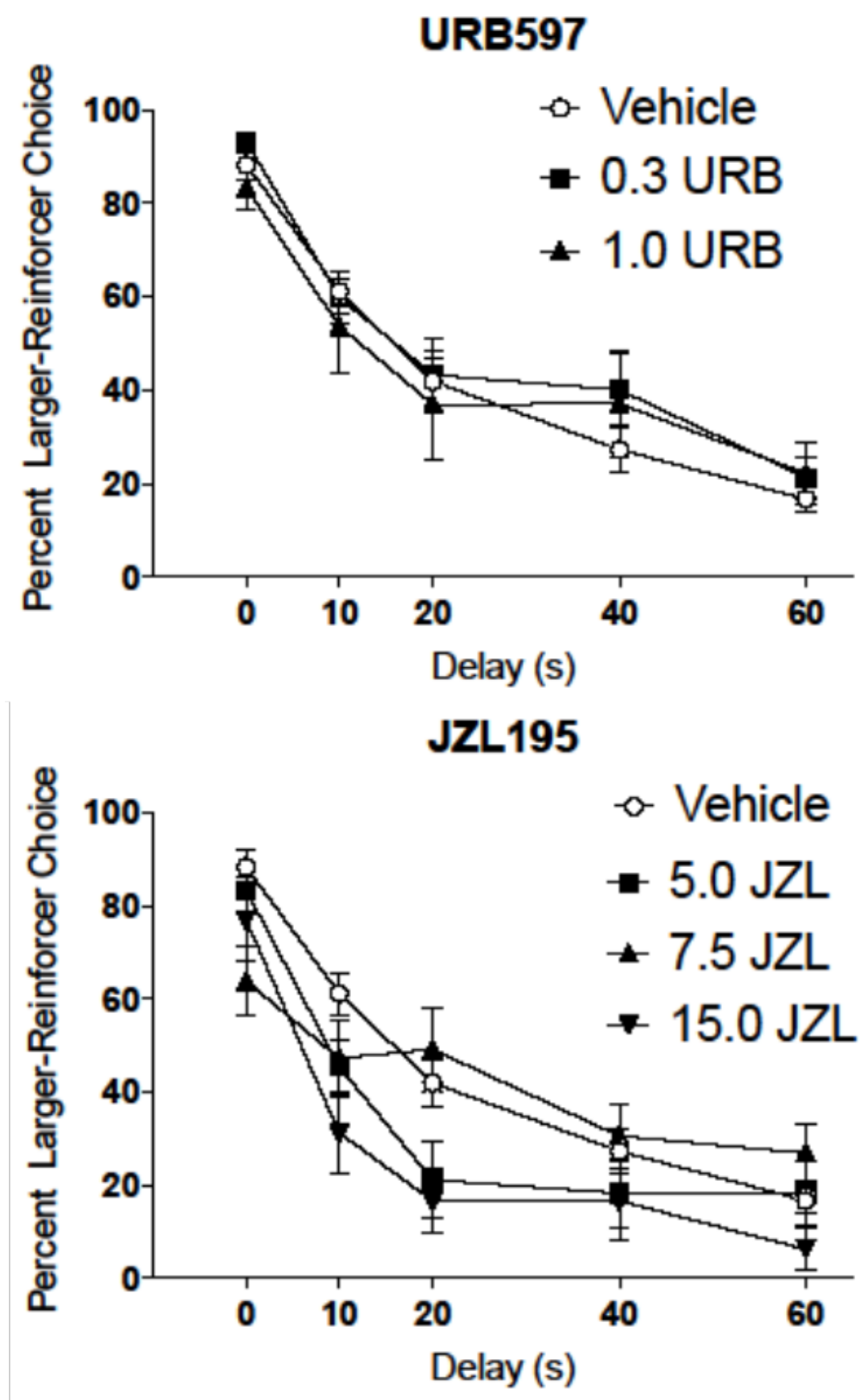

Figure 1. Mean percentages of larger-reinforcer choice for all rats when vehicle, URB597 (top panel) or JZL195 (bottom panel) were administered. All doses are presented in mg/kg. Error bars indicate standard error of the mean (SEM). 


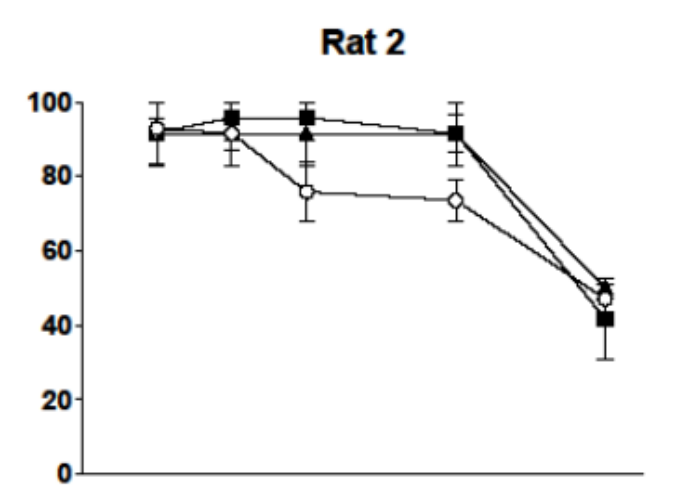

- Control

Rat 3

* 0.3 URB

$\star 1.0$ URB

$\rightarrow 3.0$ URB
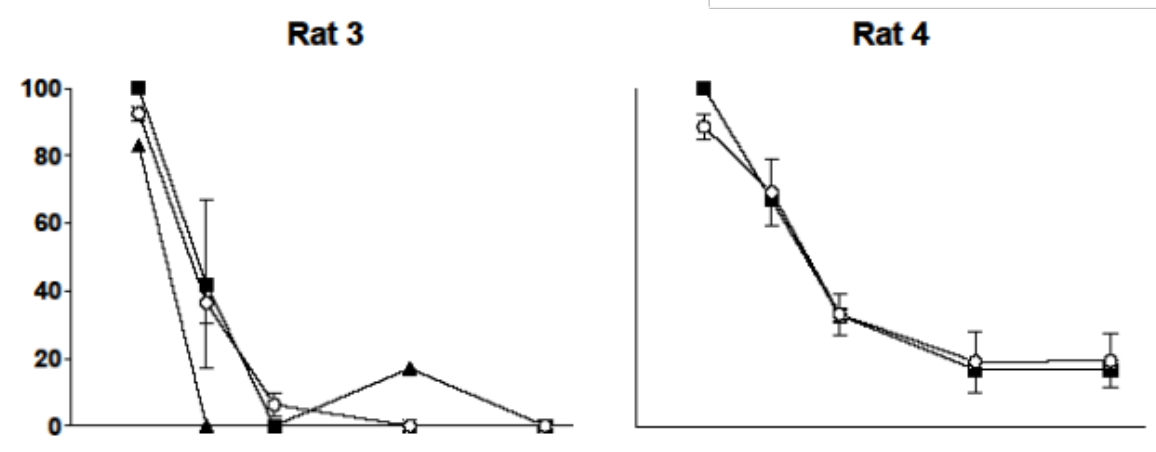

Rat 5

Rat 6
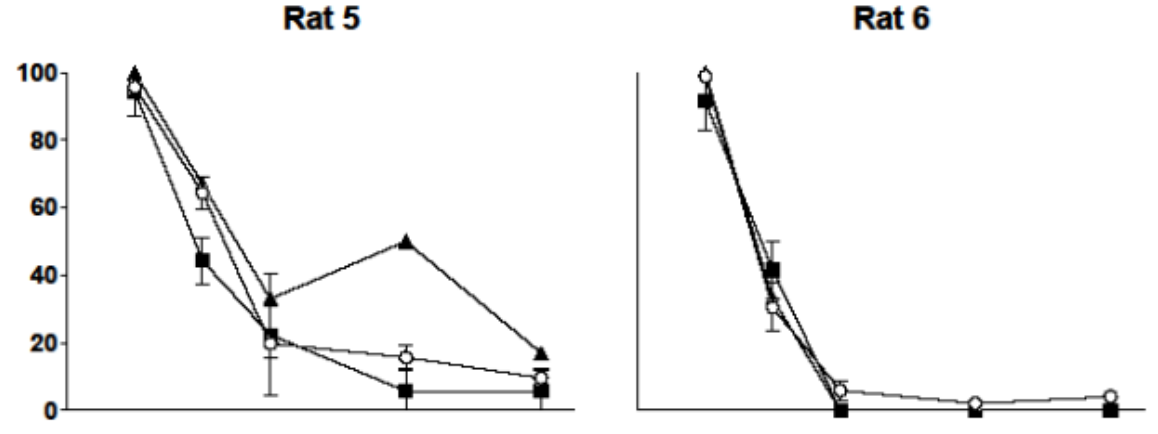

Rat 7

Rat 8
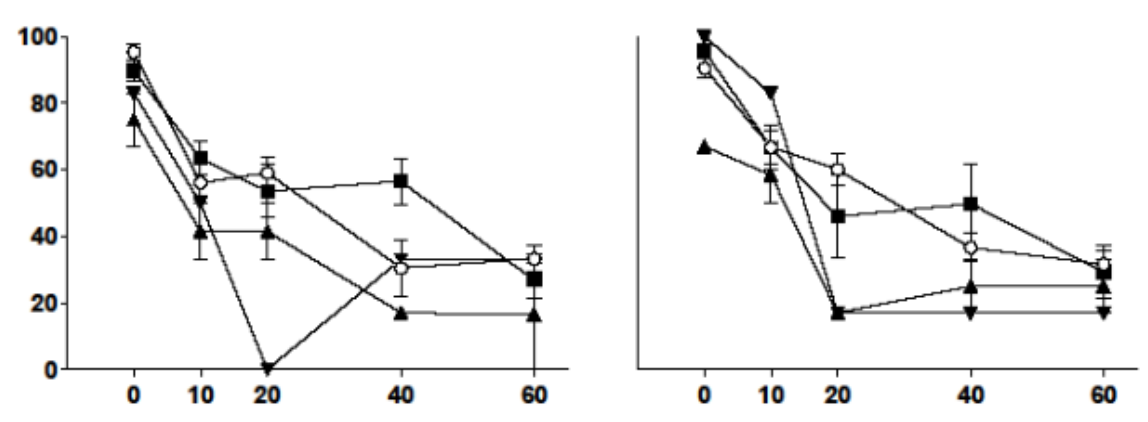

Figure 2. Mean percentages of larger-reinforcer choice for individual rats when vehicle or URB597 was administered. All doses are presented in mg/kg. Error bars indicate SEM. 


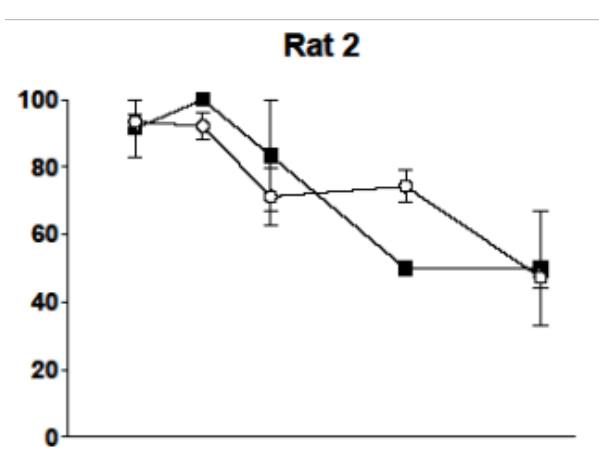

Rat 3

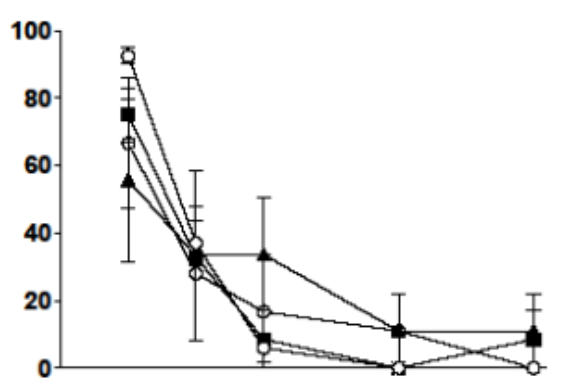

Rat 5

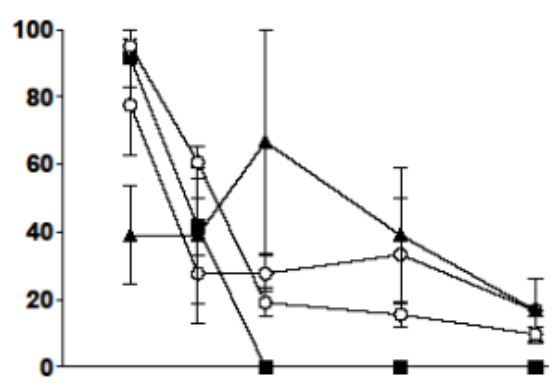

Rat 7

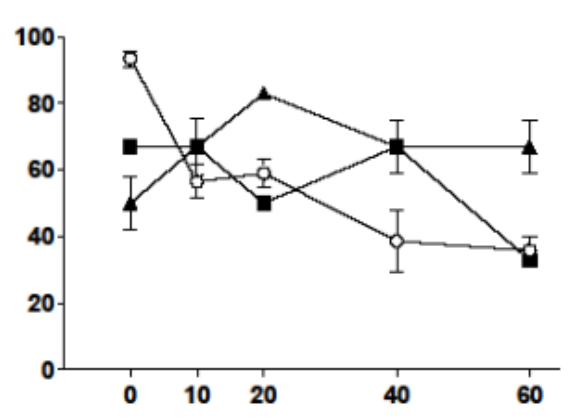

-o- Control

$-5.0 \mathrm{JZL}$

$+7.5 \mathrm{JZL}$

$+15.0 \mathrm{JZL}$

Rat 4

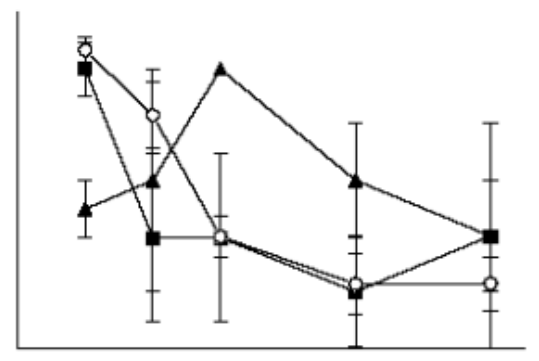

Rat 6

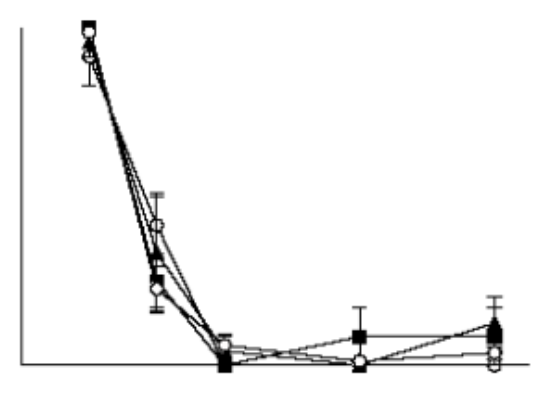

Rat 8

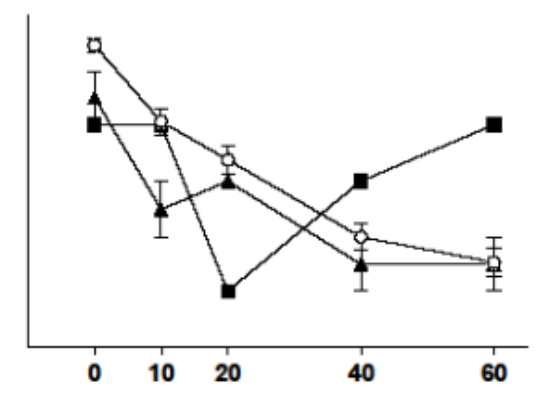

Figure 3. Mean percentages of larger-reinforcer choice for individual rats when vehicle or JZL195 was administered. All doses are presented in mg/kg. Error bars represent SEM. 


\section{Appendix}

Glossary of Abbreviations and Acronyms

- 5-HT - Serotonin, a neurotransmitter known to be involved in impulsivity.

- DA - Dopamine, a neurotransmitter known to be involved in impulsivity.

- $\quad$ PFC - Prefrontal Cortex, a brain region known to be involved in impulsivity.

- $\quad$ NAc - Nucleus Accumbens Core, a brain region known to be involved in impulsivity.

- AUC - Area Under the Curve, a common measure of impulsivity.

- $\quad$ CB1 - Cannabinoid Receptor type 1, the cannabinoid receptor found predominantly in the brain and nervous system.

- CB2 - Cannabinoid Receptor type 2, the cannabinoid receptor found predominantly on immune cells and tissue.

- 2-AG - 2-arachidonoylglycerol, an endogenous cannabinoid

- AEA - Anandamide, an endogenous cannabinoid

- FAAH - Fatty Acid Amide Hydrolase, the enzyme responsible for the majority of AEA degradation.

- MAGL - Monoacylglycerol Lipase, the enzyme responsible for the majority of 2-AG metabolism. 